\title{
Serum Levels of Testosterone in Patients with Polycythemia Vera
}

\author{
Hiroshi Fujita1, Akira Ohwada², Shigeko Nishimura1 \\ ${ }^{1}$ Department of Transfusion Medicine, Tokyo Metropolitan Bokutoh Hospital, Tokyo, Japan \\ ${ }^{2}$ Department of Internal Medicine, Tokyo Metropolitan Bokutoh Hospital, Tokyo, Japan \\ Email: hiroshi_fujita@tmhp.jp
}

Received 28 July 2016; accepted 13 August 2016; published 16 August 2016

Copyright (C) 2016 by authors and Scientific Research Publishing Inc.

This work is licensed under the Creative Commons Attribution International License (CC BY). http://creativecommons.org/licenses/by/4.0/

(c) () Open Access

\begin{abstract}
Despite its association with vascular events such as myocardial and cerebral infarction, polycythemia vera (PV) is characterized by low serum total cholesterol levels. Because several sex hormones are derived from cholesterol, statins may induce hypogodanism in male patients. Therefore, we assessed the relationship between serum total cholesterol and sex hormone levels according to gender. Medical records of 41 patients with erythrocytosis (hemoglobin concentrations: men >18.5 g/dL; women >16.5 g/dL) collected between August 2005 and December 2014 were reviewed for patient age, and gender, as well as clinical hematology, biochemistry, and endocrinology laboratory findings. Serum levels of testosterone were lower in men with PV than in patients with reactive erythrocytosis (RE) (PV: $385 \pm 78 \mathrm{ng} / \mathrm{mL}$ versus RE: $529 \pm 46 \mathrm{ng} / \mathrm{mL}$ ). However, serum levels of testosterone in women with PV were comparable to those in patients in the nonerythrocytic group (PV: $20.5 \pm 3.5 \mathrm{ng} / \mathrm{mL}$ versus non-erythrocytic group: $21.0 \pm 4.3 \mathrm{ng} / \mathrm{mL}$ ). Serum levels of testosterone were not related to serum levels of cholesterol. Therefore, we speculated that lower testosterone levels were not due to lower serum levels of cholesterol, a known adverse effect of statin. In conclusion, we report for the first time that serum levels of testosterone were lower in male PV patients than in those with RE; however, serum levels of testosterone in female patients with PV were not lower.
\end{abstract}

\section{Keywords}

Polycythemia Vera, JAK2 V617F Mutation, Hypocholesterolemia, Testosterone

\section{Introduction}

Because several sex hormones are derived from cholesterol, statins may induce hypogodanism such as erectile dysfunction in male patients through severe hypocholesterolemia [1] [2]. Although some types of statins have been shown to improve erectile dysfunction [3] [4], their effects were not due to sex hormone production. Be- 
cause erectile dysfunction is often associated with endothelial dysfunction, statins may improve endothelial function by reducing serum cholesterol levels.

Moreover, statins also inhibit testosterone synthesis in animal experiments [5]. Statins significantly reduced luteinizing hormone (LH)-stimulated testosterone production in rat Leydig cells, suggesting two possible mechanisms by which statins might induce decreased testosterone levels. First, statins may reduce serum levels of testosterone due to hypocholesterolemia [1] [2]. Second, statins may inhibit testosterone synthesis [5].

However, we previously reported that serum levels of total cholesterol, low-density lipoprotein cholesterol, and apolipoprotein B were significantly lower in patients with polycythemia vera (PV) than in those with reactive erythrocytosis (RE) without the Janus Kinase 2 (JAK2) V167F gene mutation [6]. PV is classified as a myeloproliferative neoplasm and typically occurs in people $60-79$ years of age. Thrombotic events such as myocardial infarction, cerebral infarction, and deep vein thrombosis are the main clinical complications of PV [7]. The $J A K 2$ gene mutation has become an important criterion for the diagnosis of PV as the JAK2 V617F mutation is observed in approximately $95 \%$ of patients with PV [8]. However, other mutations involving $J A K 2$ exon 12, the Von Hippel-Lindau Tumor Suppressor (VHL) gene, and hypoxia-inducible factor-2 are also associated with idiopathic erythrocytosis [9] [10].

Thus, we revisited the relationship between serum total cholesterol levels and sex hormones, especially testosterone, from the viewpoints of gender differences. We reported that serum levels of testosterone in male patients with PV were lower than those in patients with RE, while serum levels of testosterone in female patients with PV were almost equal to those in non-erythrocytic females, in spite of the presence of hypocholesterolemia in female patients with PV.

\section{Patients and Methods}

\subsection{Patients}

Tokyo Metropolitan Bokutoh Hospital is located in eastern Tokyo. We retrospectively reviewed the medical records of 34 patients at this hospital with erythrocytosis (hemoglobin [Hb]: men, $>18.5 \mathrm{~g} / \mathrm{dL}$; women, $>16.5$ $\mathrm{g} / \mathrm{dL}$ ), collected between August 2005 and December 2014. The medical records were reviewed for patient age, gender, and laboratory test results. Patients taking medications such as statins for hypercholesterolemia were excluded from this study. Male and female patients were divided into PV and reactive erythrocytosis (RE) groups according to World Health Organization (WHO) classifications. The non-erythrocytic subjects included both medically healthy workers under 65 years of age and hypertensive patients without hyperlipidemia $>65$ years of age $(\mathrm{N}=18)$. All subjects provided informed consent for their participation in the study, and the study design was approved by the ethics review board of our institution.

\subsection{Methods}

Venous blood was collected into evacuated tubes in order to measure the sex hormone profile (testosterone, free testosterone, estrogen, follicle-stimulating hormone [FSH], $\mathrm{LH}$, and corticosteroids) during initial phlebotomy tests in our department. Serum samples were collected, frozen immediately, and stored at $-80^{\circ} \mathrm{C}$ until further analysis. The serum hormone profiles were measured by the BML company (Tokyo, Japan).

\subsection{Statistical Analyses}

We compared the differences between the PV and reactive erythrocytosis groups, or non-erythrocytosis groups by Wilcoxon's analysis. Data were expressed as group means \pm standard errors of the mean or medians with interquartile ranges. All statistical calculations were performed using JMP version 8.0 (SAS Institute, Inc., Cary, $\mathrm{NC}$ ), and significance was defined as $\mathrm{p}<0.05$.

The correlations between serum levels of cholesterol and sex hormones were assessed by linear regression analysis. For the linear regression analysis results, significance was defined as $p<0.0001$.

\section{Results}

\subsection{Sex Hormone Levels in Male Patients with PV}

Of 41 patients with erythrocytosis, 21 were diagnosed with PV. The other 13 patients with erythrocytosis tested 
negative for the $J A K 2$ V617F mutation and were thus not diagnosed with PV (reactive erythrocytosis, RE). The patients with $\mathrm{RE}$ were all male $(\mathrm{N}=13)$, and seven male patients were diagnosed with PV. We compared the clinical profiles, hematology, biochemistry (cholesterol and albumin), and sex hormone findings among male patients with PV $(\mathrm{N}=7)$, non-PV erythrocytosis $(\mathrm{N}=13)$ and non-erythrocytosis $(\mathrm{N}=11)$, as shown in Table 1. Male patients with PV had significantly lower body mass index (BMI) than did those with RE. Serum cholesterol levels in patients with PV were lower than those with RE and those in the non-erythrocytic group. Among sex hormones, serum testosterone and estradiol levels were significantly lower in patients with PV than in patients with RE, as shown in Table 1.

There was no correlation between serum levels of cholesterol and sex hormones (testosterone: $r^{2}=0.08197, p$ $=0.1250$ and estradiol: $\mathrm{r}^{2}=0.08952, \mathrm{p}=0.1082$ ).

\subsection{Sex Hormones in Female Patients with PV}

Among the female patients in this study, 11 had PV, and none had RE. Therefore, we compared the clinical, hematology, cholesterol, and sex hormone profiles between the PV $(\mathrm{N}=14)$ and non-erythrocytosis $(\mathrm{N}=7)$ groups. There were no differences in BMI or sex hormone levels between the PV and non-erythrocytosis groups, although serum cholesterol levels in patients with PV were significantly lower than those in patients with nonerythrocytosis (Table 2).

Table 1. Clinical profiles, hematology, serum cholesterol and sex hormone levels in male patients with erythrocytosis.

\begin{tabular}{|c|c|c|c|}
\hline & $\begin{array}{l}\text { Polycythemia vera } \\
\qquad=7\end{array}$ & $\begin{array}{l}\text { Reactive erythrocytosis } \\
\qquad N=13\end{array}$ & $\begin{array}{c}\text { Non-erythrocytosis } \\
\mathbf{N}=\mathbf{1 1}\end{array}$ \\
\hline \multicolumn{4}{|l|}{ Clinical profile } \\
\hline Age & $60(4)$ & $64(3)$ & $67(2)$ \\
\hline Height $(\mathrm{cm})$ & $168(3)$ & $164(3)$ & $161(2)$ \\
\hline Weight $(\mathrm{kg})$ & $61(4)$ & $67(4)$ & $60(3)$ \\
\hline Body mass index & $21(1)^{*}$ & $25(1)$ & $23(1)$ \\
\hline \multicolumn{4}{|l|}{ Hematology } \\
\hline Red blood cells $\left(\times 10^{4} / \mu \mathrm{L}\right)$ & $717(36)^{* \#}$ & $586(12)$ & $449(14)$ \\
\hline Hemoglobin $(\mathrm{g} / \mathrm{dL})$ & $19.5(0.4) \#$ & $19.7(0.3) \#$ & $14.2(0.3)$ \\
\hline Hematocrit $(\%)$ & $59.3(1.3) \#$ & $57.6(1.1) \#$ & $42.5(0.9)$ \\
\hline Mean Corpuscular volume (fL) & $83.8(3.5)^{*} \#$ & $98.4(1.5)$ & $94.8(2.1)$ \\
\hline Platelet $\left(\times 10^{4} / \mu \mathrm{L}\right)$ & $36.7(7.1)^{* \#}$ & $16.5(0.8)$ & $20.4(1.2)$ \\
\hline White blood cells $(/ \mu \mathrm{L})$ & $17,257(4491)^{* \#}$ & $6,408(309)$ & $5,727(415)$ \\
\hline \multicolumn{4}{|l|}{ Biochemistry } \\
\hline Total cholesterol $(\mathrm{mg} / \mathrm{dL})$ & $163(12) \#$ & $186(8)$ & $190(9)$ \\
\hline Serum albumin $(g / d L)$ & $4.5(0.1)$ & $4.4(0.1)$ & $4.3(0.1)$ \\
\hline \multicolumn{4}{|l|}{ Sex hormone profile } \\
\hline $\mathrm{LH}(\mathrm{mIU} / \mathrm{mL})$ & $5.9(1.7)$ & $7.2(0.8)$ & $6.9(1.4)$ \\
\hline $\mathrm{FSH}(\mathrm{mIU} / \mathrm{mL})$ & $16.7(4.5)$ & $9.1(1.0)$ & $14.1(3.6)$ \\
\hline Testosterone $(\mathrm{ng} / \mathrm{mL})$ & $385(78)^{*}$ & $529(46)$ & $570(55)$ \\
\hline Free testosterone $(\mathrm{pg} / \mathrm{mL})$ & $8.0(2.0)$ & $8.5(0.8)$ & $7.5(1.0)$ \\
\hline Estradiol $(\mathrm{pg} / \mathrm{mL})$ & $17.1(4.1)^{* \#}$ & $28.5(2.5)$ & $28.4(3.0)$ \\
\hline Cortisol $(\mu \mathrm{g} / \mathrm{dL})$ & $13.5(3.7)$ & $12.0(1.1)$ & $13.1(1.0)$ \\
\hline
\end{tabular}

Data are shown as means (standard errors). *: $\mathrm{p}<0.05$ vs. reactive erythrocytosis; \#: $\mathrm{p}<0.05$ vs. non-polycythemic subjects; Reference value for sex hormones in men; Luteinizing hormone: 0.8 - $5.7 \mathrm{mIU} / \mathrm{mL}$; Follicle-stimulating hormone: 2.0 - $8.3 \mathrm{mIU} / \mathrm{mL}$ Testosterone: 229 - 1,039 ng/dL; Free testosterone: 50 - 59 yrs: 6.9 - 18.4, 60 - 69 yrs: 5.4 - 16.7, 70 - 79 yrs: 4.5 - 18.8; Estradiol: 19 - $51 \mathrm{pg} / \mathrm{mL}$; Cortisol: $4.5-21.1 \mu \mathrm{g} / \mathrm{dL}$. 
Table 2. Clinical profiles, hematology, serum cholesterol, and sex hormone levels in female patients with erythrocytosis.

\begin{tabular}{|c|c|c|}
\hline & $\begin{array}{l}\text { Polycythemia vera } \\
\mathrm{N}=14\end{array}$ & $\begin{array}{c}\text { Non-erythrocytosis } \\
\quad \mathbf{N}=7\end{array}$ \\
\hline \multicolumn{3}{|l|}{ Clinical profile } \\
\hline Age & $70(2)$ & $74(2)$ \\
\hline Height $(\mathrm{cm})$ & $151(8)$ & $154(5)$ \\
\hline Weight $(\mathrm{kg})$ & $54(3)$ & $50(2)$ \\
\hline Body mass index & $23(1)$ & $21(1)$ \\
\hline \multicolumn{3}{|l|}{ Hematology } \\
\hline Red blood cells $\left(\times 10^{4} / \mu \mathrm{L}\right)$ & $726(21) \#$ & $410(14)$ \\
\hline Hemoglobin (g/dL) & $18.2(0.5) \#$ & $13.0(13.6)$ \\
\hline Hematocrit (\%) & $57.4(1.0) \#$ & $39.0(0.9)$ \\
\hline Mean Corpuscular volume (fL) & $80(3) \#$ & $95(2)$ \\
\hline Platelet $\left(\times 10^{4} / \mu \mathrm{L}\right)$ & $47.0(4.8) \#$ & $21.0(2.1)$ \\
\hline White blood cells $(/ \mu \mathrm{L})$ & $15,350(1,858) \#$ & $5443(56)$ \\
\hline \multicolumn{3}{|l|}{ Biochemistry } \\
\hline Total cholesterol (mg/dL) & $159(5) \#$ & $193(10)$ \\
\hline Serum albumin $(\mathrm{g} / \mathrm{dL})$ & $4.1(0.1)$ & $4.3(0.1)$ \\
\hline \multicolumn{3}{|l|}{ Sex hormone profile } \\
\hline $\mathrm{LH}(\mathrm{mIU} / \mathrm{mL})$ & $19.4(1.4)$ & $19.1(2.7)$ \\
\hline FSH $(\mathrm{mIU} / \mathrm{mL})$ & $51.1(5.9)$ & $46.7(6.2)$ \\
\hline Testosterone (ng/mL) & $20.5(3.5)$ & $21.0(4.3)$ \\
\hline Free testosterone $(\mathrm{pg} / \mathrm{mL})$ & $16.4(6.0)$ & $8.8(2.2)$ \\
\hline Estradiol (pg/mL) & $12.3(0.7)$ & $15.1(2.7)$ \\
\hline Cortisol $(\mu \mathrm{g} / \mathrm{dL})$ & & \\
\hline
\end{tabular}

Data are shown as means (standard errors). \#: $\mathrm{p}<0.05$ vs. non-polycythemic subjects; Reference values for sex hormones in women; Luteinizing hormone after menopause: 5.7 - $64.3 \mathrm{mIU} / \mathrm{mL}$; Follicle-stimulating hormone after menopause: $<157.8 \mathrm{mIU} / \mathrm{mL}$; Testosterone: 33.0 - $126 \mathrm{ng} / \mathrm{dL}$; Estradiol after menopause: $<39 \mathrm{pg} / \mathrm{mL}$; Cortisol: $4.5-21.1 \mu \mathrm{g} / \mathrm{dL}$.

\section{Discussion}

\subsection{Serum Levels of Cholesterol and Sex Hormones in Patients with PV}

There are two possible mechanisms by which statins might induce lower testosterone levels. First, statins may reduce serum testosterone levels via hypocholesterolemia [1] [2]. Serum levels of cholesterol in the male patients were lower than those in patients with RE and the non-erythrocytic group in this study, as shown in Table 1. However, lower cholesterol levels were not related to lower hormone (testosterone and estradiol) levels. In addition, serum levels of testosterone in female patients with PV were the same as those in the non-erythrocytic group, although the serum levels of cholesterol in female patients with PV were lower than those in the nonerythrocytic group. These data suggested that lower cholesterol levels were not related to lower testosterone levels. Second, lower LS levels may inhibit testosterone synthesis [5]. However, serum levels of LH and FSH in the male patients with PV in this study were not lower than those in the RE and non-erythrocytic groups. Therefore, it was likely that there was no LH-stimulated testosterone production in male patients with PV. Thus, our hypothesis that hypocholesterolemia might induce lower testosterone levels was mistaken.

\subsection{Serum Levels of Testosterone Might Be Down-Regulated by Negative Feedback}

Testosterone itself stimulates erythropoietin production and increases hematocrit [11]. Polycythemia is a known adverse effect of testosterone treatment for hypogonadism [12]. Moreover, in the chronic mountain sickness, serum testosterone levels increase with high hematocrit [13] [14]. Therefore, one possibility that serum testosterone may be down-regulated by negative feedback system in the male patients with PV, while erythropoietin 
production is down-regulated by negative feedback system in the patients with PV [8]. We previously reported that serum levels of granulocyte-colony stimulating factor (G-CSF) in the patients with PV were lower than those in patients with with RE [15]. We speculate serum levels of testosterone may be down-regulated as same as erythropoietin and G-CSF. However, we do not understand the mechanism by which serum levels of estradiol in the male patients with PV were also lower than those in patients with RE. There is a rare case report showing the relationship between estrogen and polycythemia [16]. Estrogen is usually produced from testosterone during the aromatase activation. Aromatase inhibitors may increase testosterone, resulting from erythrocytosis. In our study, lower serum levels of testosterone in the male patients with PV affected lower serum levels of estrogen, in spite of the presence of aromatase.

Typical therapy for elderly patients with PV includes the use of hydroxyurea, which may induce hypogonadism [17]. However, while no patients in our study had hypogonadism, we should be aware of the potential for hypogonadism in male patients with PV after administration of hydroxyurea.

\section{Conclusion}

To our knowledge, this is the first study to report that serum levels of testosterone are lower in male PV patients than in those with RE.

\section{Acknowledgements}

The authors have no conflicts of interest to report. The authors alone are responsible for the content and writing of this article. This study was supported by a grant from the Tokyo Metropolitan Government.

\section{References}

[1] Cai, X., Tian, Y., Wu, T., Cao, C.X., Bu, S.Y. and Wang, K.J. (2014) The Role of Statins in Erectile Dysfunction: A Systematic Review and Meta-Analysis. Asian Journal of Andrology, 16, 461-466. http://dx.doi.org/10.4103/1008-682X.123678

[2] Schooling, C.M., Yeung, S.L.A., Freeman, G. and Cowling, B.J. (2013) The Effect of Statins on Testosterone in Men and Women, a Systematic Review and Meta-Analysis of Randomized Controlled Trials. BMC Medicine, $11,57$. http://dx.doi.org/10.1186/1741-7015-11-57

[3] Kostis, J.B. and Dobrzynski, J.M. (2014) The Effects of Statins on Erectile Dysfunction: A Meta-Analysis of Randomized Trials. The Journal of Sexual Medicine, 11, 1626-1635. http://dx.doi.org/10.1111/jsm.12521

[4] Trivedi, D., Kirby, M., Wellsted, D.M., Ali, S., Hackett. G., O’Connor, B. and van Os, S. (2013) Can Simvastatin Improve Erectile Dysfunction and Health-Related Quality of Life in Men Aged $\geq 40$ Years with Erectile Dysfunction? Results of the Erectile Dysfunction and Statins Trials. BJU International, 111, 324-333. http://dx.doi.org/10.1111/j.1464-410X.2012.11241.x

[5] Klinefelter, G.R., Laskey, J.W. and Amann, R.P. (2014) Statin Drugs Markedly Inhibit Testosterone Production by Rat Leydig Cells in Vitro: Implications for Men. Reproductive Toxicology, 45, 52-58. http://dx.doi.org/10.1016/j.reprotox.2013.12.010

[6] Fujita, H., Hamaki, T., Handa, N., Ohwada, A., Tomiyama, J. and Nishimura, S. (2012) Hypocholesterolemia in Patients with Polycythemia Vera. Journal of Clinical and Experimental Hematopathology, 52, 85-89. http://dx.doi.org/10.3960/jslrt.52.85

[7] Tartaglia, A.P., Goldberg, J.D., Berk, P.D. and Wasserman, L.R. (1986) Adverse Effects of Antiaggregating Platelet Therapy in the Treatment of Polycythemia Vera. Seminars in Hematology, 23, 172-176.

[8] Vardiman, J.W., Thiele, J., Arber, D.A., Brunning, R.D., Borowitz, M.J., Porwit, A., Harris, N.L., Le Beau, M.M., Hellstrom-Lindberg, E., Tefferi, A. and Bloomfield, C.D. (2009) The 2008 Revision of the World Health Organization (WHO) Classification of Myeloid Neoplasms and Acute Leukemia: Rationale and Important Changes. Blood, 114, 937-951. http://dx.doi.org/10.1182/blood-2009-03-209262

[9] McMullin, M.F. (2009) Idiopathic Erythrocytosis: A Disappearing Entity. Hematology, 2009, 629-635. http://dx.doi.org/10.1182/asheducation-2009.1.629

[10] Scott, L.M., Tong, W., Levine, R.L., Scott, M.A., Beer, P.A., Stratton, M.R., Futreal, P.A., Erber, W.N., McMullin, M.F., Harrison, C.N., Warren, A.J., Gilliland, D.G., Lodish, H.F. and Green, A.R. (2007) JAK2 Exon 12 Mutations in Polycythemia Vera and Idiopathic Erythrocytosis. The New England Journal of Medicine, 356, 459-468.

http://dx.doi.org/10.1056/NEJMoa065202 
[11] Bachman, E., Travison, T.G., Basaria, S., Davda, M.N., Guo, W., Li, M., Connor Westfall, J., Bae, H., Gordeuk, V. and Bhasin, S. (2014) Testosterone Induces Erythrocytosis via Increased Erythropoietin and Suppressed Hepcidine: Evidence for a New Erythropoietin/Hemoglobin Set Point. Journals of Gerontology Series A: Biological Sciences and Medical Sciences, 69, 725-726. http://dx.doi.org/10.1093/gerona/glt154

[12] Jones Jr., S.D., Dukovac, T., Sangkum, P., Yafi, F.A. and Hellstrom, W.J.G. (2015) Erythrocytosis and Polycythemia Secondary to Testosterone Replacement Therapy in the Aging Male. Sexual Medicine Reviews, 3, 101-112. http://dx.doi.org/10.1002/smrj.43

[13] Gonzales, G.F. (2013) Serum Testosterone Levels and Excessive Erythrocytosis during the Process of Adaptation to High Altitudes. Asian Journal of Andrology, 15, 368-374. http://dx.doi.org/10.1038/aja.2012.170

[14] Gonzales, G.F., Gasco, M., Tapia, V. and Gonzales-Castaneda, C. (2009) High Serum Testosterone Levels Are Associated with Excessive Erythrocytosis of Chronic. Mountain Sickness in Men. American Journal of Physiology: Endocrinology and Metabolism, 296, E1319-E1325. http://dx.doi.org/10.1152/ajpendo.90940.2008

[15] Fujita, H., Hamaki, T., Ohwada, A., Tomiyama, J. and Nishimura, S. (2011) Serum Levels of Granulocyte ColonyStimulating Factor Are Lower in JAK2 V617F Positive versus Negative Erythrocytosis. International Journal of Laboratory Hematology, 33, e20- e21. http://dx.doi.org/10.1111/j.1751-553X.2011.01336.x

[16] Yeruva, S.L.H., Nwabudike, S.M., Ogbonna, O.H. and Oneal, P. (2015) Aromatase Inhibitor-Induced Erythropoiesis INA Patient Undergoing Hormonal Treatment for Breast Cancer. Case Reports in Haematology, 2015, Article ID: 784783.

[17] Beeson, M., Antiwi, E.K. and Vesely, D.L. (1999) Hydroxyurea-Induced Hypogodanism. Endocrinologist, 9, $389-390$. http://dx.doi.org/10.1097/00019616-199909000-00010

\section{Submit or recommend next manuscript to SCIRP and we will provide best service for you:}

Accepting pre-submission inquiries through Email, Facebook, LinkedIn, Twitter, etc.

A wide selection of journals (inclusive of 9 subjects, more than 200 journals)

Providing 24-hour high-quality service

User-friendly online submission system

Fair and swift peer-review system

Efficient typesetting and proofreading procedure

Display of the result of downloads and visits, as well as the number of cited articles

Maximum dissemination of your research work

Submit your manuscript at: http://papersubmission.scirp.org/ 